\title{
Construction on Network Teaching Resources for Chinese International Education Specialty
}

\author{
Hong Zhou \\ College of International Exchange, Bohai University, Jinzhou, 121013, China \\ 642510571@qq.com
}

\begin{abstract}
Keywords: Chinese international education; network teaching resources; system construction; resource website; system function
\end{abstract}

\begin{abstract}
With the gradual development of network education, network teaching resources become increasingly rich, the construction of teaching resources is the key to carry out network education. In order to meet the needs of the Chinese international education in the teaching of information technology. The research content mainly includes four aspects: the comparison and analysis of the main teaching resources website in Chinese international education, the advantages of the Chinese international education network teaching resources, the design of the Chinese international education network teaching resource system, the research of the Chinese International Education network. The research content of this paper is to solve the core problem of the construction of the network teaching resources of the Chinese international education, which has important theoretical and practical significance to promote the development of International Education in Chinese.
\end{abstract}

\section{Introduction}

Chinese international education is not only a systematic and solid basic knowledge and skills of Chinese language and literature, but also a cross-cultural communication theory. It has a high quality and a wide knowledge of related disciplines. It can be used to exchange and teaching. It can be used in foreign language teaching and foreign language teaching [1]. After graduation, students can apply for language, linguistics and applied linguistics, international Chinese Language Education Master's degree, can be engaged in foreign language teaching in the University, after the national exam and selection can volunteer and Chinese language teachers as a second language teaching work, can also be in the domestic training institutions, Chinese Language School and international, primary school teaching or teaching management work, can also be engaged in other departments.

Teaching resources is the effective teaching material and can be used to the conditions, usually including textbooks, case studies, videos, pictures and courseware, including teacher resources, teaching aids, such as infrastructure, teaching materials and information sources. Under the trend of Chinese international promotion, foreign language teaching has received unprecedented attention at home and abroad, with the rapid development of opportunities and challenges. To adapt to this new situation, the quantity and variety of teaching resources has changed, the new technology and products, the full range of expansion, the key and technological innovation has also spawned a new pattern and new methods of teaching Chinese as a foreign language. Network teaching resources are not limited by time and space, call students enthusiasm and interaction, sharing of resources and other characteristics, can provide learning support and service, provide the experience of Chinese culture of the soil, to provide remote teaching environment". In this paper, we study the construction of network teaching resources in the Chinese international education, which is to adapt to the development of network teaching.

\section{Main Teaching Resources Website of Chinese International Education}

The existing network resources of the foreign language, mainly including the navigation kind website, the comprehensive information portal, the Chinese proficiency test website, the language and the text research website, the experience exchange website, the teaching website, the cultural 
resources station, etc.. At present, the main teaching resources of International Education in Chinese language teaching resources are shown in Table 1.

Table 1. Main teaching resources website of Chinese international education

\begin{tabular}{|c|c|c|c|}
\hline No & $\begin{array}{l}\text { Resource } \\
\text { name }\end{array}$ & $\begin{array}{c}\text { Resource } \\
\text { URL }\end{array}$ & Resource synopsis \\
\hline 1 & $\begin{array}{l}\text { National } \\
\text { Chinese } \\
\text { office } \\
\text { network }\end{array}$ & $\begin{array}{c}\text { http://w } \\
\text { ww.hanb } \\
\text { an.edu.c } \\
\mathrm{n} /\end{array}$ & $\begin{array}{l}\text { Sponsored by the office of the national Chinese international promotion leading } \\
\text { group, the relevant provisions of the relevant provisions of the domestic and foreign } \\
\text { relevant provisions of the Chinese teaching of foreign language, HSK examination, } \\
\text { and the relevant provisions of the foreign language teachers training and } \\
\text { examination. The teaching resources include the digital library of the Kong Zi } \\
\text { Institute, the global Chinese material library, the international Chinese teaching case } \\
\text { library and the examination Resources. }\end{array}$ \\
\hline 2 & $\begin{array}{l}\text { HSK } \\
\text { dynamic } \\
\text { composition } \\
\text { corpus }\end{array}$ & $\begin{array}{l}\text { http://20 } \\
2.112 .19 \\
5.8 / \mathrm{hsk} / 1 \\
\text { ogin.asp }\end{array}$ & $\begin{array}{l}\text { Non-native Chinese speakers in the corpus of the HSK advanced composition exam } \\
\text { answers, collect the part of the foreign students of composition writing papers, } \\
\text { corpus total to } 11569 \text { article. The use of the corpus in the composition of the corpus, } \\
\text { can carry out the teaching of Chinese as a foreign language. }\end{array}$ \\
\hline 3 & $\begin{array}{c}\text { My Chinese } \\
\text { net }\end{array}$ & $\begin{array}{c}\text { http://w } \\
\text { ww.mym } \\
\text { andarin.c } \\
\text { om/ }\end{array}$ & $\begin{array}{l}\text { Sponsored by Canada's "my Chinese net" network company, mainly for the } \\
\text { Canadian overseas Chinese as well as in the North American region to English } \\
\text { speaking Chinese learners. Network resources include: China and the world in other } \\
\text { parts of the world, the latest information on Chinese language teaching, HSK test } \\
\text { the latest news, online Chinese teaching and exchange between friends, etc.. }\end{array}$ \\
\hline 4 & $\begin{array}{l}\text { Chinese } \\
\text { language } \\
\text { and text } \\
\text { network }\end{array}$ & $\begin{array}{l}\text { http://w } \\
\text { ww.chin } \\
\text { a-langua } \\
\text { ge.gov.c } \\
\mathrm{n} /\end{array}$ & $\begin{array}{l}\text { Under the leadership of the Ministry of education and the State Language } \\
\text { Commission, sponsored by the State Language Work Committee, Ministry of } \\
\text { education language application to host the event. The purpose is to promote the } \\
\text { national language policy, service social language life, and guide the society to use } \\
\text { the language of the motherland correctly, improve the national language literacy, } \\
\text { promote academic research and exchange. }\end{array}$ \\
\hline 5 & $\begin{array}{l}\text { se } \\
\text { ge } \\
\text { ces } \\
\text { ce }\end{array}$ & $\begin{array}{c}\text { www.chi } \\
\text { neseldc.o } \\
\text { rg }\end{array}$ & $\begin{array}{l}\text { Is representative of the international } \mathrm{le} \\
\text { common language information and } \mathrm{kn} \\
\text { systematic and open features, covering } \mathrm{Ch} \\
\text { language and voice resources, including } \mathrm{di}\end{array}$ \\
\hline 6 & $\begin{array}{l}\text { Network } \\
\text { Kong Zi } \\
\text { college }\end{array}$ & $\begin{array}{c}\text { http://w } \\
\text { ww.chin } \\
\text { esecio.co } \\
\mathrm{m} /\end{array}$ & $\begin{array}{l}\text { Services in the global Chinese language learners and the global Confucius Institute } \\
\text { of teachers and students of the integrated portal, to provide Chinese language } \\
\text { learners and enthusiasts to learn Chinese language courses, to understand Chinese } \\
\text { culture, sharing learning experience, as well as to provide a platform for teaching } \\
\text { Chinese language teaching and sharing teaching experience. }\end{array}$ \\
\hline 7 & $\begin{array}{l}\text { Chinese } \\
\text { education } \\
\text { network }\end{array}$ & $\begin{array}{c}\text { http://w } \\
\text { ww.hwjy } \\
\text { w.com/ }\end{array}$ & $\begin{array}{l}\text { Has nine channels, such as "China education information, Chinese teaching } \\
\text { materials, online classroom, resource center, Chinese culture, youth activities, } \\
\text { Chinese teaching community, pictures, video" and other channels, through the } \\
\text { provision of quality courses, teachers training courses, Chinese teaching materials, } \\
\text { Chinese traditional culture lectures and other content, service overseas Chinese } \\
\text { school teachers, students and other enthusiastic Chinese learners. }\end{array}$ \\
\hline 8 & $\begin{array}{l}\text { National } \\
\text { foreign } \\
\text { language } \\
\text { test } \\
\text { information } \\
\text { network }\end{array}$ & $\begin{array}{l}\text { http://w } \\
\text { ww.dwh } \\
\text { y123.co } \\
\mathrm{m} /\end{array}$ & $\begin{array}{l}\text { Integration of domestic and foreign advantages of foreign language education, } \\
\text { training, examination and other resources in the field of learning, to provide the } \\
\text { most comprehensive, the most authoritative information platform for online } \\
\text { information. The first time to publish a variety of learning, examination, training, } \\
\text { information, and the domestic major training institutions and well-known distance } \\
\text { education institutions to provide the most effective, the most comprehensive } \\
\text { network courses learning opportunities. }\end{array}$ \\
\hline
\end{tabular}

The successful teaching resources website should have the following characteristics: the content is relatively new, the update rate is very high; the user segment, is not to copy the traditional teaching material to make courseware, but according to the actual needs of the user; the open content is more, the interactive link is more; the service is thoughtful and timely. But there are some problems in the current international education of the Chinese International Education: the content of network learning resources is lack of or stale, redundant construction; content retrieval, knowledge map, path guidance is not clear; the network learning resource organization is disordered, online services are backward; the network learning resource is not good. 


\section{Advantage on Network Teaching Resources of Chinese International Education}

The development of modern information technology has provided technical support for the construction of the teaching of Chinese as a foreign language. In the face of the international environment of Chinese hot, the latest achievements of modern information technology should be used to provide a personalized and diversified learning environment for the Chinese international education service, which provides a personalized and diversified learning environment for second language learners with different learning degrees, different nationalities and different learning objectives. In the Chinese international education, the use of network teaching resources have the following advantages [2-4]:

(1) Teaching resources. Network with infinite space, through the network can transfer all kinds of multimedia information, and broke the situation of traditional education in the single teaching information, rich teaching resources, show the latest teaching content of the modern science and technology, reflects the new trends of the development of the discipline, the learners can be convenient for online access to teaching resources, collect a lot of relevant professional information, reading or discussing the sense of intellectual interest, feelings of the network.

(2) Flexibility in learning style. Students can choose courses, teachers, learning progress and learning time, you can query their own curriculum and materials, online learning can be real-time, that is, different teachers, students at the same time to carry out teaching activities; also can be non real time, that is, the teacher will be teaching content and requirements stored in the server, students according to their own time to download online learning.

(3) Teaching mode diversity. The single teaching mode of traditional teaching is not conducive to students' ability and innovative thinking, which is not conducive to the cultivation of students' learning interest. Using network teaching resources, the demonstration, task driven, group collaboration, flip the classroom and other teaching mode, fully reflects the students' main position, enhance the students' awareness of autonomous participation and cooperation and exchange, students use the operation to explore the unknown field, to cultivate team spirit.

(4) Knowledge information integration. Network teaching emphasizes the diversity of knowledge and information resources, and according to the teaching requirements, to provide a variety of resource reuse technology, through the processing of knowledge, combination and finishing, knowledge, meaning, ideas, values, emotions, and so on.

\section{Function on Network Resources System of Chinese International Education}

The most commonly used method of functional design is simulation, which is the result of the modular structure. Function frame structure is a function of the system function to decompose, according to the function of the relational representation of the graphics, each rectangle is called a function module. Functional modules can be based on the specific circumstances, the smallest of modules can be a program in each processing process, and the larger function can be a group of procedures to complete a task. The Chinese international education network teaching resources system includes four modules: system management, resource management, resource sharing, resource management, and each upper module contains a number of modules, as shown in Fig.1 [5].

\section{Development on Network Teaching Resources of Chinese International Education}

Teaching resource collection is the pre work of development. Chinese international education network resource collection should follow the following principles: the principle of [6], a wide variety of online materials, the lack of effective teaching information resources integration, the targeted is not strong. The core courses of Chinese foreign language students, foreign students and master's degree in international education, pay attention to the analysis of students' knowledge background, learning rules and learning interest, optimize the network resources, collect and integrate culture teaching resources; the practical principle, the collection and production of teaching resources from the perspective of Teachers teaching, students learning, take full 
consideration of the teaching environment, curriculum syllabus, teaching objects and other factors, reduce the blind use of resources. It is convenient for teachers to optimize the teaching content, choose, combine and form the classroom teaching courseware, easy to use in class, improve the efficiency and effect of the lesson.

\begin{tabular}{|c|c|}
\hline System configuration management & Resources cataloging service \\
\hline Personalized page control & Resources usage tracking \\
\hline Cataloging information transmission & Resources upload or download \\
\hline Proxy user management & Resources maintenance \\
\hline IP address management & Resources browse \\
\hline User privileges assignment & Resources retrieval \\
\hline User information management & Resources release \\
\hline User registration management & Resources audit \\
\hline Data distributed storage & Resources Batch \& single warehousing \\
\hline Data backup and recovery & Resource base structure management \\
\hline System management & Resources management \\
\hline \multicolumn{2}{|c|}{ Resource server, directory server, Web server, application server } \\
\hline Resources communication & Resources operation \\
\hline Resources network exchange & Resources operation mode \\
\hline Resources directory synchronization & Resources operation rules \\
\hline Resources synchronous communication & Resources accounting management \\
\hline Resources asynchronous communication & Using statistical analysis \\
\hline Resources exchange rules & Resources recommendation recognition \\
\hline Resources system update & User use tracking \\
\hline
\end{tabular}

Fig. 1. Function on network resources system of Chinese international education

Network resource development generally includes analysis, design, production, testing and evaluation process, as shown in Fig. 2. The results of the test and evaluation are satisfactory, the development is over; if not satisfied, it may be an analysis, design or production of any stage of the problem, to return to this stage to revise and improve $[7,8]$.



Fig. 2. Development process on network teaching resource

(1) Resource analysis. Mainly from four aspects: teaching target analysis, including cognitive, emotional, action skills, learning analysis, including learning style, knowledge level, network level, learning expectations, network conditions, including hardware and network with and software; investigation research, whether there are similar resources can learn from the curriculum, the resources and materials are easy to get.

(2) Resource design. Is the core of the whole development process, the design level directly 
determines the quality of the development of resources. Mainly from three aspects: the overall design, including teaching scheme design and technical scheme design, detailed design and decision of each specific teaching knowledge point of realization way; adaptive teaching design, for different learners with different learning path.

(3) Resource production. The plan of the pre plan is put into practice, and the knowledge points in the course of the course are interpreted one by one, and the function modules of the design are realized. To seriously assess the workload, and on this basis to develop a reasonable schedule of the course, the system is composed of video capture, audio capture, screen capture and recording four parts, etc..

(4) Testing and evaluation. After the completion of the resource development, we must test and evaluate the resources in accordance with the analysis results, the overall design and detailed design of the script. Because the network teaching resources should be uploaded to the Internet, so after the test is passed, the need for resources to pack, import the existing network teaching support platform or upload to the specified server.

\section{Conclusion}

Chinese international education information is the basic elements of the Chinese international education system, which is widely used in the various fields of the Chinese international education to promote the development of the Chinese international education. Under the background of the information of the language, in the face of the phenomenon of global Chinese fever continues to heat up, the network teaching resources for the Chinese International Education and its promotion to provide a broader platform. The research content of this paper is to solve the core problem of the construction of network teaching resources in the Chinese international education, which has important theoretical and practical significance.

\section{References}

[1] X. L Cui, "On the Discipline Orientation of TCSOL," Chinese Teaching in the World, vol. 29, no. 3, pp. 405-411, 2015.

[2] Y. Q. Zheng, "New Thinking on International Chinese Education against the Background of Information Technology in the New Era," Journal of International Chinese Teaching, vol. 2, no. 2, pp. 26-33, 2015.

[3] F. Q. Wang, "Current situation and Countermeasure of network teaching resources construction," Education and Vocation, vol. 97, no. 9, pp. 162-163, 2013.

[4] Rio Tinto network technology, "Network teaching platform has what advantage," http://www.ltpower.net/List.aspx?C-1-586.Html, 2015-11-20.

[5] Baidu pictures ,"Management system distributed education resource management system," http://image.baidu.com/search/detail?ct $=503316480 \& \mathrm{z}=0 \& \mathrm{ipn}=\mathrm{d} \&$ word= Education resource system\%20picture\&step_word=\&pn=33\&spn=0\&di=61 148676930\&pi=\&rn=1\&tn=baiduimag edetail\&is $=\&$ istype $=01-120406131435133$.png\&fromurl=ippr_z2C\%24qAzdH3FAzdH3Fooo_ z\%26e3Bfjj25p_z\%26e3BvgAzdH3FwAzdH3Fujgk7fitzty7wgAzdH3F\&gsm=0, 2015-11-20.

[6] S. C. Jing, S. Y. Sun, "Probing into Production Method of Web-based Teaching and Learning Resources," Journal of Tianjin Radio and Television University, vol. 16, no. 4, pp. 32-36, 2012.

[7] L. Hou, "On the integration and construction of Chinese culture teaching resources in the Chinese International Education," Contemporary Educational Science, vol. 16, no. 28, pp. 57-59, 2013.

[8] Z. Miao, "Reflects on Chinese international education informatization construction," Master's degree of Huazhong Normal University, 2014. 